\title{
A New Species of Cletocamptus Copepoda (Harpacticoida, Canthocamptidae) from Salt Marshes in Korea
}

\author{
Cheon Young Chang* \\ Department of Biological Science, Daegu University, Gyeongsan 712-714, Korea
}

\begin{abstract}
A new copepod species, Cletocamptus koreanus, is described from estuaries and salt marshes on south and southwest coasts in Korea. Cletocamptus koreanus n. sp. evidently belongs to $C$. deitersi species group in sharing 6- segmented antennule, 3 setae on antennary exopod, leg 1 with endopod shorter than exopod, and $2+1$ inner setae on the third exopodal segments of legs 3-4. However, C. koreanus is distinguished from its allied congeneric species by different setal armatures of mandibular palp, antennary exopod, endopod of female leg 2 and the third exopodal segments of legs 3-4, and relative length and shape of apophysis of male leg 3 enp 2. Description and taxonomic accounts of the new species are presented herein, with detailed illustrations and scanning electron microscope photomicrographs. Discussion on the affinities with other species of $C$. deitersi group are provided, along with brief comments on the morphological discrepancies between the new species from Korea and other Asian species from China and India.
\end{abstract}

Keywords: brackish, Cletocamptus koreanus, description, SEM, taxonomy

\section{INTRODUCTION}

A series of faunistic papers relating to harpacticoid copepods from various brackish waters in Korea have been published: Harpacticella itoi Chang and Kim, 1991 by Chang and Kim (1991), two Mesochra species by Lee and Chang (2003), two Onychocamptus species by Lee and Chang (2005), two new species of Neotachidius by Huys et al. (2005), three Cletodidae species by Lee and Chang (2007), Nitokra koreanus Chang, 2007 and Ameira parvula (Claus, 1886) by Chang (2007), two Leptocaris species by Lee and Chang (2008a), five Nitokra species by Chang and Yoon (2008), two new species of Itunella arenaria and Mesochra bisetosa by Lee and Chang (2008b), four Tachidiidae species by Chang (2008), and three Miraciidae species by Chang (2009b) (see Chang, 2010 for details).

As one of the serial studies on the brackish copepod fauna, the author re-examined a brackish species collected from salt marshes on south and southwest coasts of Korea, which had been remained as an undetermined species, 'Cletocamptus sp.' in his book (Chang, 2009a). It is evidently related to
C. deitersi (Richard, 1897), and seemingly identical to ' $C$. deitersi' sensu Tai and Song, 1979 from southern China. As discussed and summarized by Gómez et al. (2004), numerous worldwide records identified as 'Cletocamptus deitersi', including the one from China, have turned out to be the different distinct species or the species inquirendae.

As the above-mentioned Cletocamptus species from Korea has turned out to be new to science in the present study, herein we provide a description with detailed illustrations and scanning electron microscope photomicrographs.

\section{MATERIALS AND METHODS}

Materials examined in the present study were collected at a brackish swamp near waterways of a salt farm located at Imjado Island, off the southwestern coast of Korea on Aug 21,2008 . Collections were made with a dipnet of $64 \mu \mathrm{m}$ mesh. Copepods were fixed and stored in $4 \%$ buffered formalin.

The process of general methods, including dissection,
(C) This is an Open Access article distributed under the terms of the Creative Commons Attribution Non-Commercial License (http://creativecommons.org/ licenses/by-nc/3.0/) which permits unrestricted non-commercial use, distribution, and reproduction in any medium, provided the original work is properly cited.

pISSN 2234-6953 eISSN 2234-8190
*To whom correspondence should be addressed

Tel: 82-53-850-6454, Fax: 82-53-850-6459

E-mail: cychang@daegu.ac.kr 
preparation, observation and measurements, follows my previous paper (Lee and Chang, 2012).

Materials for scanning electron microscopy were prefixed overnight at $4^{\circ} \mathrm{C}$ in $2.5 \%$ glutaraldehyde, followed by rinsing with $0.1 \mathrm{M}$ phosphate buffer $(\mathrm{pH} 7.2-7.4)$ three times, each for $10 \mathrm{~min}$. Specimens were postfixed for $2 \mathrm{~h}$ in $2 \%$ cold osmium tetroxide in $0.1 \mathrm{M}$ phosphate buffer, and were then left in phosphate buffer overnight. After dehydration through a graded series of ethanol (50-100\% at $10 \%$ interval) for $30 \mathrm{~min}$ each, the material was critical point dried, and coated with gold-palladium in a high evaporator, and was then examined with a scanning electron microscope (Hitachi S-4800; Hitachi, Tokyo, Japan) operated at $15 \mathrm{kV}$.

Type specimens are deposited in the National Institute of Biological Resources (NIBR), Incheon, Korea, and the specimen room of the Department of Biological Science, Daegu University (DB), Korea.

Abbreviations used in the text and figure legend follow the conventional ones frequently used in the taxonomy of copepods: A1, antennule; A2, antenna; enp 1-3 or exp 1-3, the first to third endopodal or exopodal segment of each leg.

\section{SYSTEMATIC ACCOUNTS}

Order Harpacticoida Sars, 1903

Family Canthocamptidae Brady, 1880

Genus Cletocamptus Shmankevitsch, 1875

$1 *$ Cletocamptus koreanus n. sp. (Figs. 1-6)

Type. Holotype 우 (NIBRIV0000271765), allotype $\sigma^{7}$ (NI BRIV0000271766), undissected in $4 \%$ buffered formalin; brackish swamp beside waterway through salt farms, Imjado Island, off southwestern coast of Korea ( $35^{\circ} 03^{\prime} 24.33^{\prime \prime} \mathrm{N}$, $126^{\circ} 06^{\prime} 08.40^{\prime \prime} \mathrm{E}$ ), 21 Aug 2008 (leg. Lee J). Paratypes: 5 우 우, $2 \sigma^{\top} \sigma^{\nearrow}$ (DB20033-20039), dissected in lactophenol, collection details same as in holotype.

Additional material examined: Korea: 2 우 우 (DB20040), dissected in lactophenol, Busan, Jinudo islet (delta) $\left(35^{\circ}\right.$ 04'08.40'N, $128^{\circ} 52^{\prime} 14.49^{\prime \prime} \mathrm{E}$ ), 8 Aug 1988 (leg. Chang CY). Description. Female: Body (Fig. 1A) cylindrical, tapering posteriorly; body length ranging from 590 to $670 \mu \mathrm{m}$ (mean $630 \mathrm{~mm}, \mathrm{n}=6$; holotype $620 \mathrm{~mm}$ ). Rostrum developed, defined at its broad base, narrowing anteriorly, with round tip, in a dorsal view. Posterior margins of all somites with spinule row. Cephalic shield covered with numerous pits or tubercles, with short hairs scattered. Next 3 prosomites (pedigerous somites 2-4) with 4-5 transverse rows of minute spinu- les, followed by long and sharp spinules along posterior margin of each somite. Genital double-somite apparently divided by subcuticular chitinous rib dorsally and laterally, but completely fused ventrally (Fig. 1A, B); ventral surface with 4-5 transverse rows of spinules laterally and 1 spinule row medially, flanked by sharp and strong spinules along posterior margin. Urosomites 3-4 with 3 spinule rows ventrally (foremost one situated medially only, next 2 rows throughout whole width of somite), followed by long and sharp spinules along posterior margin. Anal somite armed with transverse rows of long and fine spinules dorsally and with strong spinules along posterior margin of somite. Anal operculum (Figs. 1C, 6A) gently convex, with 2 rows of strong spinules, comprising 8-12 spinules along posterior margin and 8-10 strong spinules anterior to them.

Caudal rami (Figs. 1C, 6A) truncate, about 1.7 times longer than wide, a little divergent posteriorly; dorsal keel not apparent; proximal part of medial margin a little swollen with 2 oblique spinule rows along medial face. Lateral caudal setae (caudal setae I and II) located proximally; outer caudal seta (caudal seta III) absent; outer terminal caudal seta (caudal seta IV) pinnate, a little shorter than half the inner terminal caudal seta (caudal seta V); inner caudal seta (caudal seta VI) naked and slender, slightly less than 2 times as long as caudal ramus; dorsal caudal seta (caudal seta VII) situated near middle of medial margin of caudal ramus.

Antennule (Fig. 2A) 6-segmented, its tip not reaching middle of cephalothorax; segments 1-3 stout, segment 5 apparently small, segment 6 elongate; segment 4 with 1 aesthetasc, its tip much exceeding distal end of antennule. Armature formula: 1-[1], 2-[9], 3-[6], 4-[1+(1+aesthetasc)], 5-[1], 6$[9+(1+$ aesthetasc $)]$ (all setae naked). Antenna (Fig. 2B), coxa small, unarmed; allobasis with 2 abexopodal setae; exopod 1-segmented, slender, cylindrical, with 3 setae (1 medial and 2 apical) in total; free endopodal segment armed with 2 lateral spines, 5 distal elements and 1 small seta on inner distal corner. Mandible (Figs. 2C, 6D), with well developed coxal gnathobase bearing $4-5$ bicuspidate and multicuspidate teeth and 1 lobate element along distal margin and 1 lateral seta at dorsal corner; palp vestigial, represented by 1 small segment bearing 2 naked seta apically, flanked by 1 slender seta nearby. Maxillule (Figs. 3A, 6E) with praecoxal arthrite bearing 7 elements with 1 seta on frontal surface and 1 spiniform, pinnate seta posteriorly; coxal arthrite with cylindrical endite bearing 2 setae apically; exopod and endopod completely fused to basis, bearing total 9 setae apically and along anterior margin. Maxilla (Fig. 3B) armed with 2 syncoxal endites, each endite bearing 3 setal elements; allobasis forming 1 strong pectinate claw, flanked by 2 setae; endo-

Korean name: ${ }^{1 *}$ 고려뭉툭뿔장수노벌레 (신칭) 

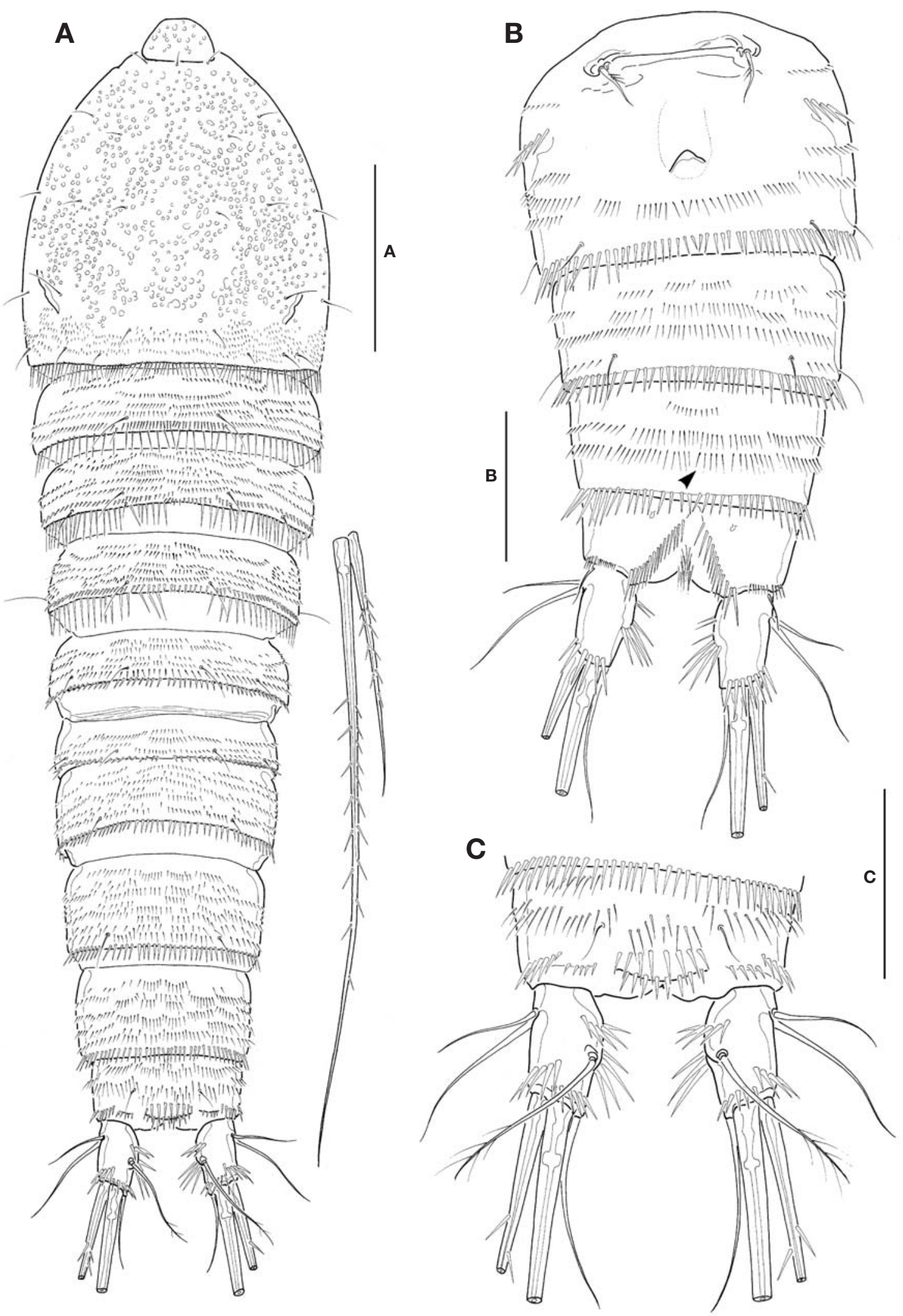

Fig. 1. Cletocamptus koreanus n. sp., female. A, Habitus, dorsal; B, Urosome, ventral; $C$, Anal somite and caudal rami, dorsal. Scale bars: $A=100 \mu \mathrm{m}, \mathrm{B}, \mathrm{C}=50 \mu \mathrm{m}$ (C after Chang 2009a). 


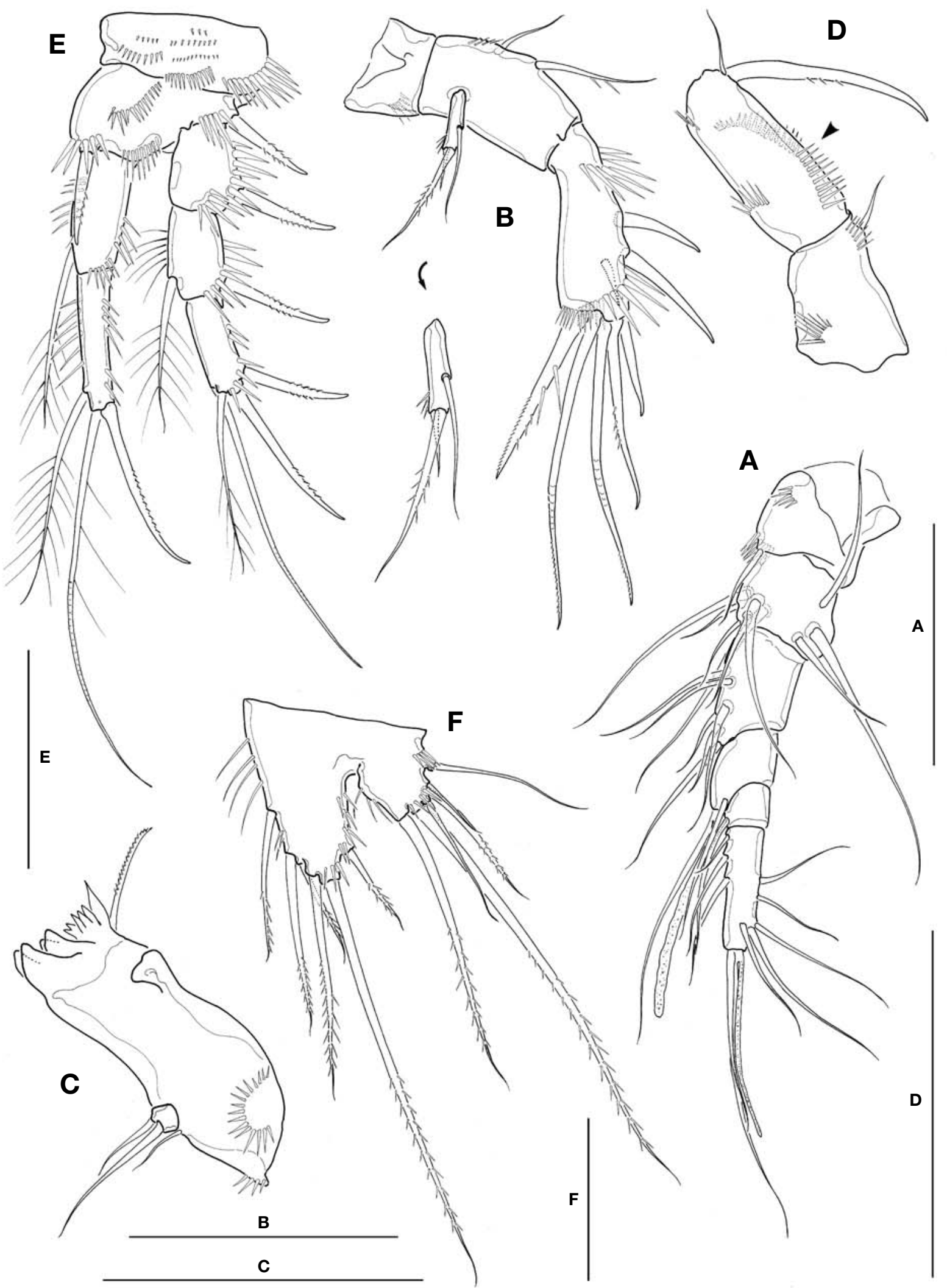

Fig. 2. Cletocamptus koreanus n. sp., female. A, Antennule; B, Antenna; C, Mandible; D, Maxilliped; E, Leg 1. Scale bars: A-F=50 $\mu \mathrm{m}$ (A, F after Chang 2009a). 


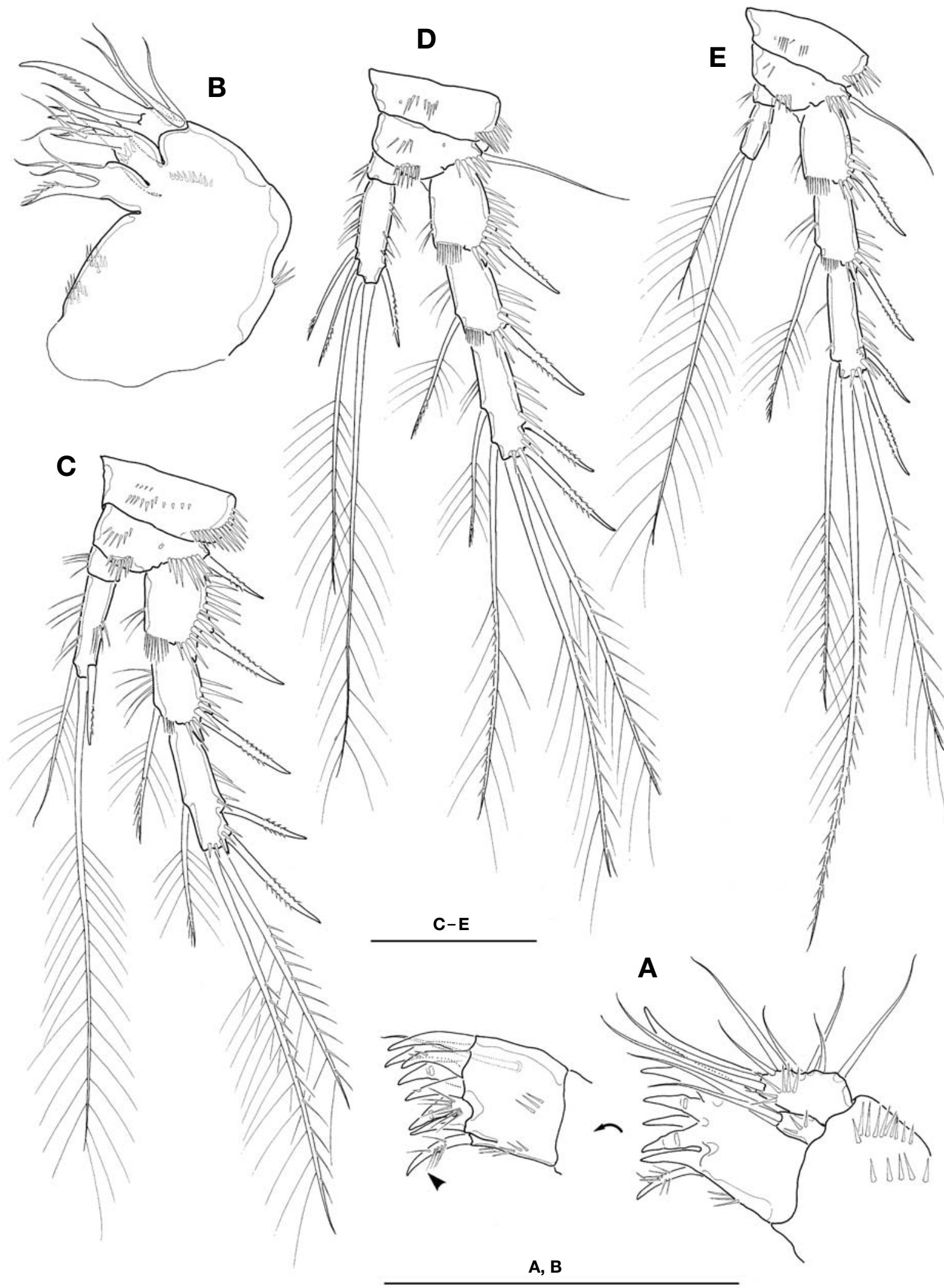

Fig. 3. Cletocamptus koreanus n. sp., female. A, Maxillule; B, Maxilla; C, Leg 2; D, Leg 3; $E$, Leg 4. Scale bars: $A-E=50 \mu m(C$, $E$ after Chang 2009a). 

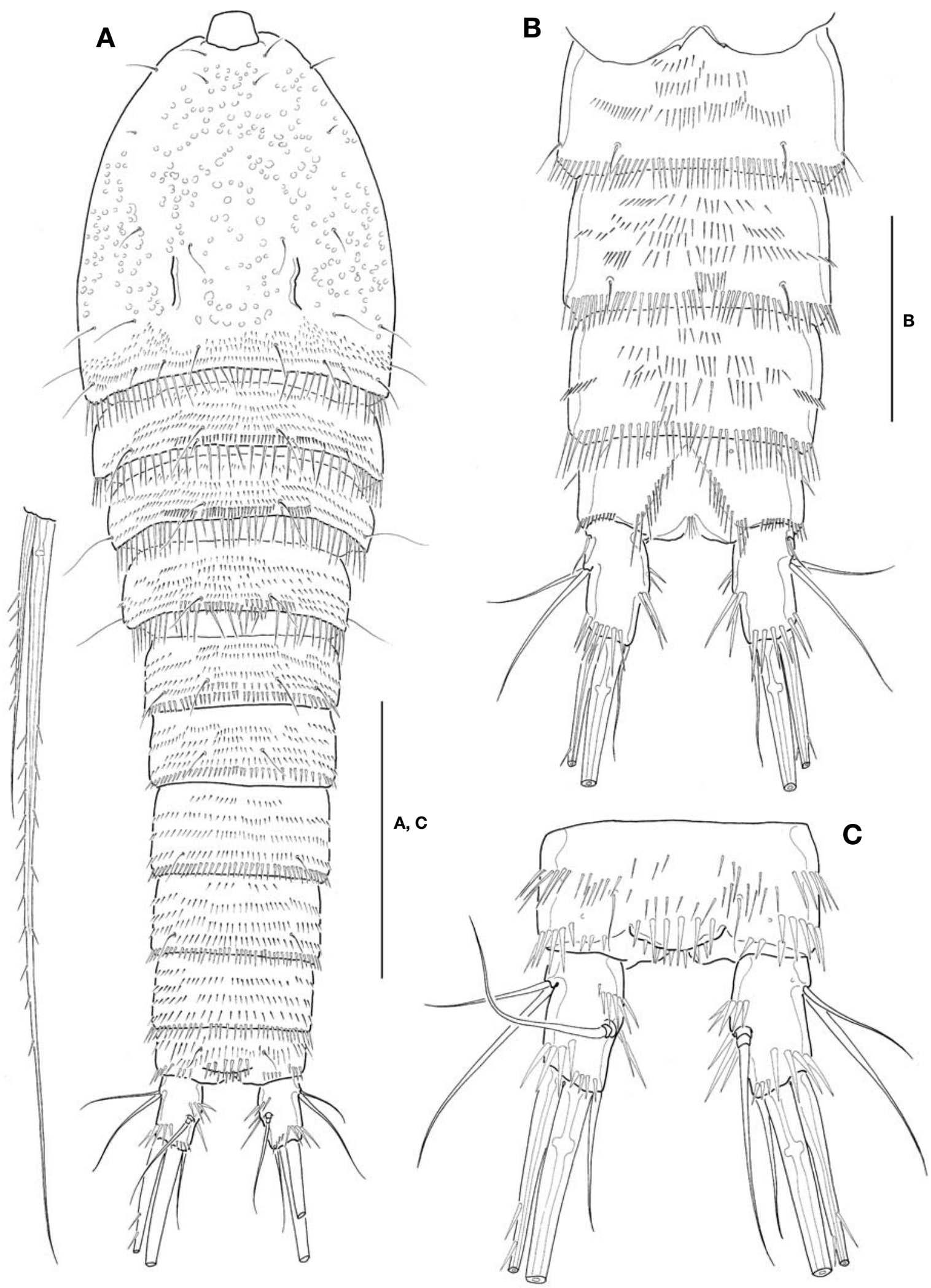

Fig. 4. Cletocamptus koreanus n. sp., male. A, Habitus, dorsal; $B$, Urosome, ventral; $C$, Anal somite and caudal rami, dorsal. Scale bars: $A-C=50 \mu \mathrm{m}$. 


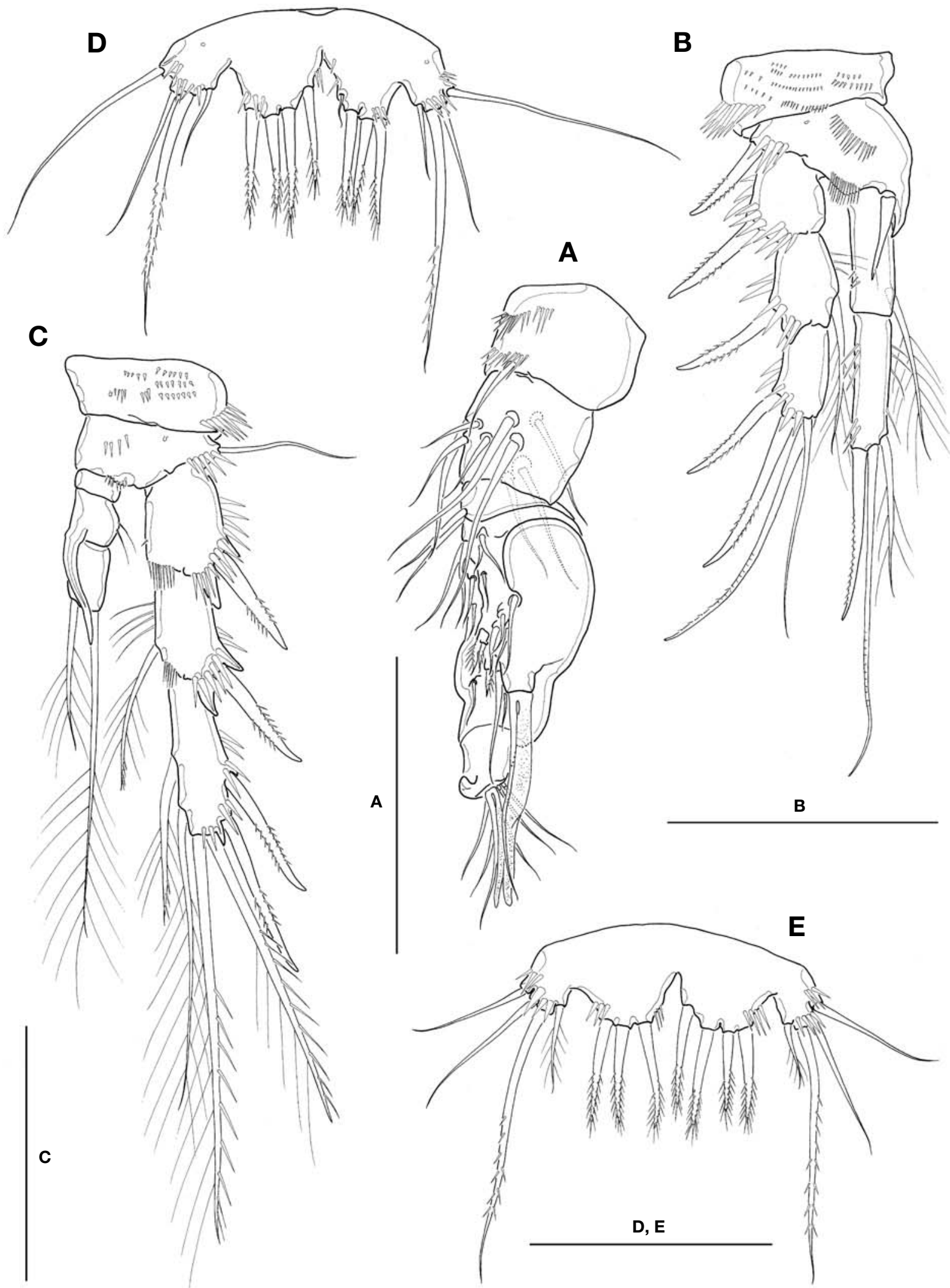

Fig. 5. Cletocamptus koreanus n. sp., male. A, Antennule; B, Leg $1 ; C$, Leg 3; $D$, Leg 5 ; $E$, Leg 5 (variation). Scale bars: $A-E=50$ $\mu \mathrm{m}$ (C, D after Chang 2009a). 

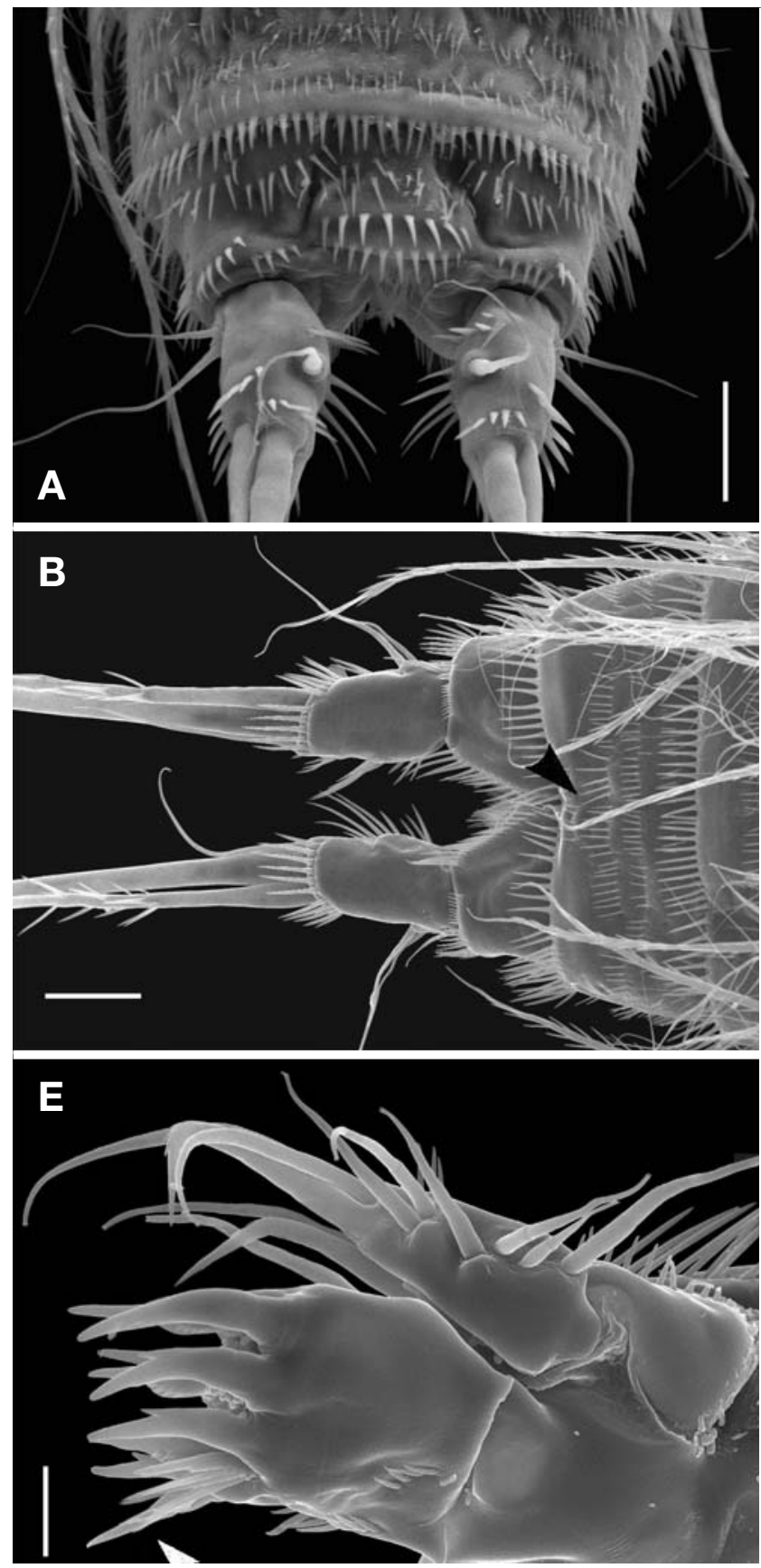
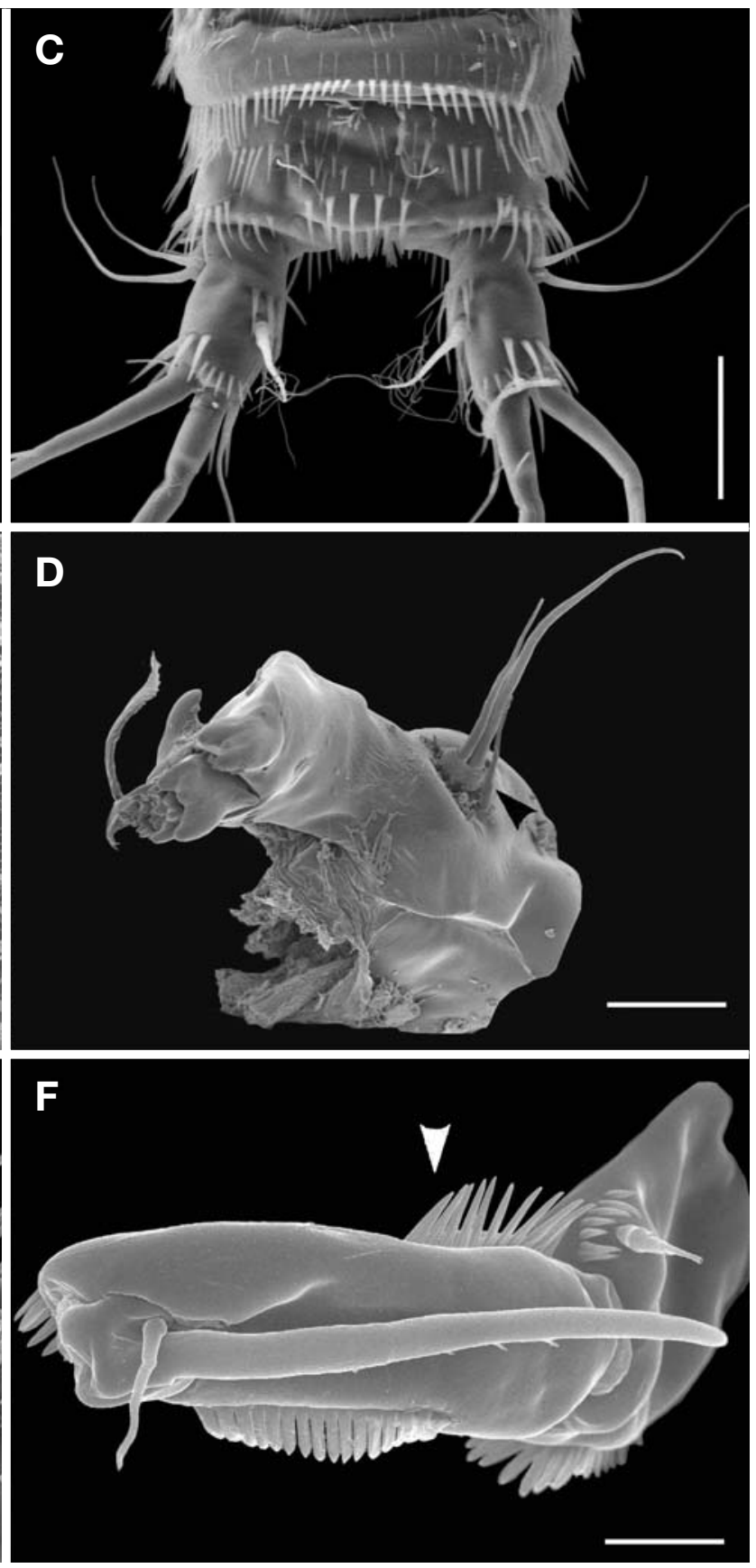

Fig. 6. Cletocamptus koreanus n. sp., scanning electron microscope micrographs. A, B, D-F, female: A, Posterior part of urosome, dorsal; B, Posterior part of urosome, ventral; D, Mandible; E, Maxillule; F, Maxilliped. C, Male: posterior part of urosome, dorsal. Scale bars: $A-C=20 \mu \mathrm{m}, D-F=10 \mu \mathrm{m}$.

pod represented by small protuberance bearing 2 naked setae. Maxilliped (Figs. 2D, 6F) subchelate; syncoxa a little protruded distomedially with 1 slender seta, flanked by spinule row at its base; basis about 3 times longer than wide, armed with longitudinal rows of spinules both anterior and post- erior surfaces along medial margin; spinule row on posterior surface consisting of 10-12 spinules, distalmost spinule not reaching halfway of medial margin of basis; endopod represented by 1 strong and curved claw, bearing 1 minute seta proximally as accessory armature. 
Legs 1-4 with 2-segmented endopods and 3-segmented exopods. Leg 1 (Fig. 2E), distomedial seta on basis not reaching posterior end of enp 1; enp 1 about 2.7 times as long as wide, slightly shorter than enp 2, not reaching distal end of $\exp 2$, with 1 inner seta distally; enp 2 with 1 inner distal plumose seta, 1 apical geniculate seta and 1 long distal spine; $\exp 2$ not elongate, with 1 inner seta; $\exp 3$ armed with 2 outer spines and 2 apical setae. Legs 2-4 (Fig. 3C-E), enp 1 small, lacking inner seta. Leg 2 enp 2 elongate, about 3.6 times as long as broad, bearing 2 plumose setae and 1 spine with 1 setule row along medial margin and 1 oblique setule row near middle of lateral margin; apical seta about 2.8 times longer than inner distal seta. Leg 3 enp 2 elongate, about 3.2 times as long as broad, bearing 4 setae and 1 spine apically or subapically; 2 inner distal setae short, modified. Leg 4 enp 2 rather ellipsoidal, bearing 2 distal setae apically. Seta/spine armature of legs 1-4 as follows:

Leg 1 basis I-1 exp I-0; I-1; II,1,1 enp 0-1; I,1,1

Leg 2 basis I-0 exp I-0; I-1; II,2,1 enp 0-0; I,1,1

Leg 3 basis 1-0 exp I-0; I-1; II,2,2 enp 0-0; I,2,2

Leg 4 basis 1-0 exp I-0; I-1; II,2,1 enp 0-0; 0,2,0

Leg 5 (Fig. 2F), baseoendopod and exopod confluent basally, bilobed distally; baseoendopod protruding, much exceeding exopod, bearing 6 setae; exopodal lobe small, wider than long, bearing 5 setae excluding baseoendopodal lateral seta, with setules along swollen medial margin.

Male: Body (Fig. 4A) about $530 \mu \mathrm{m}$ in length. General shape of body similar to that of female. Rostrum much narrower than in female. Posterior margins of third to sixth urosomites each densely lined with sharp spines; 2 spinule rows medially on ventral surface of third urosomite; 3-4 spinule rows on ventral surfaces of next 2 urosomites; setae on anal somite lappet short (Fig. 4B). Shape and armature of caudal rami nearly same as those of females, except for relatively a little longer rami, about 1.9 times as long as wide (Fig. 4C).

Antennule (Fig. 5A) subchirocerate, 6-segmented; segment 4 bulbous, armed with 3 pinnate setae and 1 aesthetasc. Leg 1 (Fig. 5B), distomedial corner of basis forming a sharp projection; inner distal seta on basis not modified, not reaching posterior end of enp 1; endopod slightly shorter than exopod; enp 1 slightly shorter than enp 2, not reaching distal end of exp 2. Leg 3 (Fig. 5C), endopod modified, 3-segmented; enp 1 lacking inner seta; enp 2 with 1 curved apophysis, its tip a little beyond distal end of enp 3; exp 2 not modified, with 1 inner seta, outer spine not swollen or elongated; exp 3 armed with 2 outer spines, 2 pinnate distal setae, 2 inner distal setae including modified, short proximal one.

Leg 5, baseoendopod and exopod confluent basally; baseoendopodal lobe bearing 4 spiniform setae, similar to each other in length, or sometimes asymmetrically armed with 3 spiniform setae and 1 slender medial seta on one side (Fig. 5D), or often with 3 spiniform setae on one side (Fig. 5E); exopodal lobe much wider than long, bearing 3 setae distally, flanking 1 long, slender basal seta outer proximally. Leg 6 represented by a genital plate, without armature (Fig. 4B).

Ecology. The present new species occurred in a salt marsh beside salt farms and its nearby waterway at Imjado Island, off the southwestern coast of the Korean Peninsula, as well as in a sandy delta (Jinudo islet) at the mouth of the Nakdong River, Busan, southeast coast of Korea. The substratum of both sites was slightly muddy sand. The species co-occurred with other brackish or coastal harpacticoid copepods: Leptocaris brevicornis (van Douwe), Nitokra lacustris (Schmankevitch), N. koreanus Chang, Schizopera neglecta Akatova, and Metis sp.

Remarks. In the genus Cletocamptus 37 species or subspecies have been recorded (Gaviria-Melo et al., 2013), of which 23 species are recognized as valid (Gómez and Gee, 2009; Pesce, 2013). The present species evidently belongs to $C$. deitersi species group in sharing the characters of 6-segmented antennule, 3 setae on antennary exopod, endopod of leg 1 shorter than exopod with 1 inner seta, and legs 3-4 exp 3 bearing 2 and 1 inner setae, respectively (Chang, 2009a).

There have been numerous records of ' $C$. deitersi' reported from whole America region, Hawaii, China, Iran, India, Malaysia and Australia, which are regarded as lots of sibling species or species inquirendae different from the genuine $C$. deitersi (Richard, 1897) from Argentine (Gómez et al., 2004). When the circumstances and the geographical distributions of $C$. deitersi group are considered, the present species from Korea, which was retained as an undetermined species ' $\mathrm{Cle}$ tocamptus sp.' by Chang (2009a), should be now treated as another distinct species.

Among the $C$. deitersi group, the present species is most similar to C. stimpsoni Gómez, Fleeger, Rocha, Oliovarez and Faltz, 2003 from Alabama, U.S.A., C. schmidti Mielke, 2000 from the Galapagos, and C. nudus Gómez, 2005 and C. levis Gómez, 2005 from Brazil in sharing comparatively not-elongated caudal rami (1.5-2 times as long as wide) and 2 -segmented endopod of leg 4 . However, the present material differs from $C$. stimpsoni by 3 setae on mandibular palp and nearby (against 2 setae in C. stimpsoni), 3 setae on antennary exopod (against 2 setae), armature of male leg 2 enp 2, and the relative length and shape of apophysis of male leg 3 enp 2; from $C$. schmidti and $C$. nudus by 3 setae on antennary exopod (against 2 setae) and 5 setae on female leg 3 enp 2 (against 3 setae); from $C$. levis by the setal armature of legs 3-4 exp 3 (2 and 1 inner setae, respectively, while 1 and 0 in C. levis) and outer spine of male leg 2 enp 2 not strongly sexually dimorphic (against modified as a curved spine in male of C. levis). 
In Asia, Tai and Song (1979) once reported the 'C. deitersi' from southern China (Kwangtung), but Gómez et al. (2004) regarded it as a species inquirenda based on an insufficient description and inadequate figures. Considering the shape and setal armature of female legs 1-5 well coincided with those of Korean specimens, the Chinese ' $C$. deitersi' sensu Tai and Song, 1979 might be identical to the present species. However, their description did not deal with male characters, and completely neglected other important characters currently adopted for the classification of the $C$. deitersi group, such as setal armature of mouthparts, especially on mandibular palp and maxillular arthrite, spinule ornamentation of anal operculum, and spinulation pattern on the surfaces of somites. So, the final decision on the genuine identity of the Chinese species should be deferred until a full-description of topotypic material from China is prepared.

Recently, Gómez et al. (2010) reported a new species as a poster presentation of the 14th International Meiofauna Conference in 2010, based on materials from an estuary on the west coast of India. According to his unpublished manuscript, which Dr. Gómez has kindly sent to me, the new species 'Cletocamptus goenchim' from the Indian Sea nearly fits the present species from Korea. In his manuscript, he also mentioned the possibility that the two species might be identical to each other. However, precise and detailed reexamination of the Korean specimens shows the consistent discrepancies from ' $C$. goenchim' as follows. 1) Leg 5 baseoendopod in male has 4 setae, or often bears 3 or 4 setae asymmetrically in C. koreanus n. sp. (cf. Fig. 5D, E), while usually bearing 3 setae on both left and right sides in ' $C$. goenchim'. In the "Variability" section of his manuscript, he did not make any comment on the variation of setal armature of leg 5 baseoendopod in male, notwithstanding the particular notes on the variation of setal armature of exopodal lobe of leg 5. Moreover, when he compared 'C. goenchim' with $C$. stimpsoni in the "Discussion" section, he asserted that the former is different from the latter by bearing 3 setae on leg 5 baseoendopod in male. So, 'C. goenchim' seems to consistently have 3 setae. 2) In female, posteriormost spinule row on preanal somite is continuous (Figs. 1B, 6B, arrowhead), and is not interrupted midventrally, as in ' $C$. goenchim'. 3) Although the size difference is rather minute, enp 2 of leg 1 is evidently longer than enp 1 in both sexes (cf. Figs. 2E, 5B), while vice versa in ' $C$. goenchim'. 4) Basis of maxilliped is elongate, about 3 times longer than wide in $C$. koreanus, n. sp., armed with longitudinal row of 10-12 spinules on posterior surface (distalmost spinule not reaching halfway of medial margin of basis) (cf. Figs. 2D, 6F, arrowhead), while basis is relatively blunt (less than 2.5 times according to his figure), with a relatively stronger spinulation extending to the distal third of basis). 5) The shape of seta on inner posterior corner of praecoxal arthrite of maxillule is stout, spiniform and pinnate (Figs. 3A, 6E), compared to the rather slender, pectinate seta in ' $C$. goenchim'.

\section{ACKNOWLEDGMENTS}

I am grateful to Dr. Samuel Gómez for allowing me his unpublished manuscript on 'Cletocamptus goenchim' from the Indian Sea. I gratefully thank Dr. Jimin Lee (Korean Institute of Ocean Science and Technology) for her help in preparing figures, and Mr. Byung-Chan Lee (Nano Practical Application Center, Daegu, Korea) for providing scanning electron microscopy facilities. I also appreciate three anonymous reviewers for their critical comments which greatly improved the manuscript. This research was supported by a Daegu University Research Grant, 2009.

\section{REFERENCES}

Chang CY, 2007. Two harpacticoid species of genera Nitokra and Ameira (Harpacticoida: Ameiridae) from brackish waters in Korea. Integrative Biosciences, 11:247-253.

Chang CY, 2008. Brackish-water copepods of the family Tachidiidae (Copepoda: Harpacticoida) from South Korea. Korean Journal of Systematic Zoology, 24:229-240.

Chang CY, 2009a. Illustrated encyclopedia of fauna \& flora of Korea. Vol. 42. Inland-water Copepoda. Ministry of Education, Science \& Engineering, Seoul, pp. 1-687.

Chang CY, 2009b. Three miraciid copepods (Harpacticoida, Miraciidae) from South Korea. Korean Journal of Systematic Zoology, 25:215-225.

Chang CY, 2010. Invertebrate fauna of Korea, Vol. 21, No. 4. Continental Harpacticoida (Arthropoda: Copepoda: Harpacticoida). National Institute of Biological Resources and Ministry of Environment, Incheon and Seoul, pp. 1-244.

Chang CY, Kim HS, 1991. Harpacticella itoi, a new harpacticoid species from Korea (Copepoda: Harpacticoida: Harpacticidae). Korean Journal of Systematic Zoology, 7:7380.

Chang CY, Yoon HJ, 2008. Nitokra copepods (Harpacticoida: Ameiridae) from Korea. Korean Journal of Systematic Zoology, 24:115-127.

Gaviria-Melo S, Boxshall G, Walter TC, Huys R, 2013. Cletocamptus Shmankevitsch, 1875. World of Copepods database, Accessed 31 Mar 2013, <http: //www.marinespecies.org/ copepoda/aphia.php? $\mathrm{p}=$ taxdetails \&id=115237>.

Gómez S, Fleeger JW, Rocha-Olivares A, Foltz D, 2004. Four new species of Cletocamptus Schmankewitsch, 1875, closely related to Cletocamptus deitersi (Richard, 1897) (Copepoda: Harpacticoida). Journal of Natural History, 38:26992732.

Gómez S, Gee JM, 2009. On four new species of Cletocamptus 
Shmankevich, 1875 (Copepoda: Harpacticoida) from inland waters of Argentina. Journal of Natural History, 43:28532910.

Gómez S, Ingole B, Sawant M, Singh R, 2010. Cletocamptus goenchim sp. nov., a new harpacticoid (Copepoda: Harpacticoida) from India. In: 14th International Meiofauna Conference, Book of abstracts (Eds., Hendrick G, Bezerra TN, Cnudde C, Deprez T, Derycke S, De Troch M, Ingels J, Merckx B, Moens T, Page E, Banaverbeke J, Vanreusel A, Vincx M), Aula Academica, Ghent, p. 121.

Huys R, Ohtsuka S, Conroy-Dalton S, Kikuchi Y, 2005. Description of two new species of Neotachidius Shen and Tai, 1963 (Copepoda, Harpacticoida, Tachidiidae) from Korean brackish waters and proposal of a new genus for Tachidius ( $\mathrm{Ta}$ chidius) vicinospinalis Shen \& Tai, 1964. Zoological Journal of Linnean Society, 143:133-159.

Lee JM, Chang CY, 2003. Taxonomy on freshwater canthocamptid harpacticoids from Korea III. Genera Mesochra and Elaphoidella. Korean Journal of Systematic Zoology, 19:203-216.

Lee JM, Chang CY, 2005. Harpacticoid copepods of genus Onychocamptus (Laophontidae) from Korea. Korean Journal of Systematic Zoology, 21:31-34.

Lee JM, Chang CY, 2007. Three cletodid copepods of the genera Limnocletodes and Kollerua (Harpacticoida, Cletodidae) from coastal marshes and estuaries in South Korea. Ocean Science Journal, 42:255-267.

Lee JM, Chang CY, 2008a. Copepods of the genus Leptocaris (Harpacticoida, Darcythompsoniidae) from salt marshes in South Korea. Korean Journal of Systematic Zoology, 24: 89-98.

Lee JM, Chang CY, 2008b. Two canthocamptid copepods of the genera Itunella and Mesochra (Harpacticoida, Canthocamptidae) from brackish waters in South Korea. Journal of Natural History, 42:1729-1747.

Lee JM, Chang CY, 2012. Discovery of the rarely known genus Psammophilocyclops (Cyclopidae Cyclopinae) from a water purification plant in South Korea. Animal Cells and Systems, 16:245-253.

Pesce GL, 2013. Harpacticoida: Cletodidae [Internet]. Copepod Web Portal, Accessed 31 Mar 2013, <http://www.luciopesce. net/copepods/chapp.htm CLETODIDAE >.

Tai AY, Song YZ, 1979. Harpacticoida Sars, 1903. In: Fauna Sinica, Crustacea, freshwater Copepoda (Ed., Shen CJ). Science Press, Peking, pp. 164-300. 